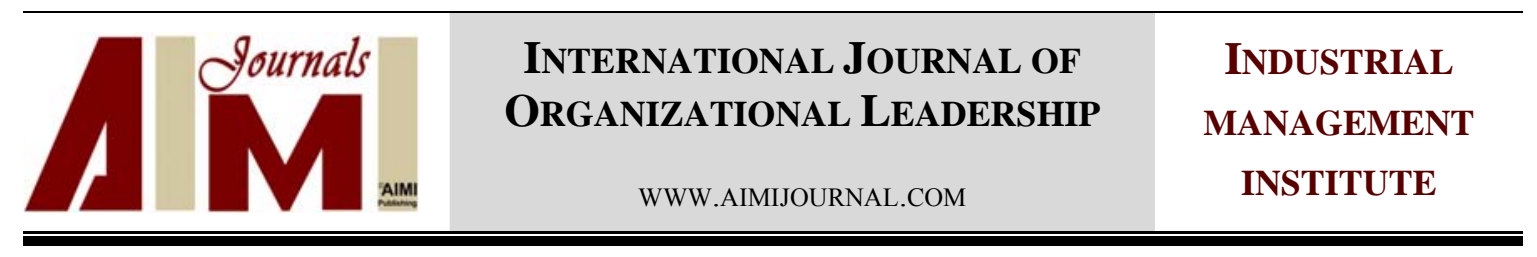

\title{
Describing model of empowering managers by applying structural equation modeling: A case study of universities in Ardabil
}

\author{
Maryam Ghahremani Germi ${ }^{1,2}$, Mohammad Hasanzadeh ${ }^{3}$ \\ 1 Department of Executive Management, Ardabil Science and Research Branch, Islamic Azad University, \\ Ardabil, Iran \\ 2 Department of Executive Management, Ardabil Branch, Islamic Azad University, Ardabil, Iran \\ 3 University of Mohaghegh Ardabili, Ardabil, Iran
}

\begin{abstract}
Keywords:

Empowerment, Clear and Challenging Goals, Evaluation of Function, Access to Resources, Rewarding System

Correspondence: m_h_ma@yahoo.com

Empowerment is still on the agenda as a management concept and has become a widely used management term in the last decade or so. The purpose of this research was describing model of empowering managers by applying structural equation modeling (SEM) at Ardabil universities. Two hundred and twenty managers of Ardabil universities including chancellors, managers, and vice presidents of education, research, and studies participated in this study. Clear and challenging goals, evaluation of function, access to resources, and rewarding were investigated. The results indicated that the designed SEM for empowering managers at university reflects a good fitness level. As it stands out, the conceptual model in the society under investigation was used appropriately. Among variables, access to resources with 88 per cent of load factor was known as the affective variable. Evaluation of function containing 51 per cent of load factor was recognized to have less effect. Results of average rating show that evaluation of function and access to resources with 2.62 coefficients stand at first level. Due to this, they had great impact on managers' empowerment. The results of the analysis provided compelling evidence that model of empowering managers was desirable at Ardabil universities.
\end{abstract}




\section{Introduction}

The main and the most important asset of any organization are its efficient and competent human resources, because competent human resources lead to creation of efficient organization. Empowerment is one of the most promising concepts of business world that has received less attention, and despite the major arguments about the advantages of empowerment, it has low utilization. Nowadays, the strategic role of it in flourishing society is highlighted (Blanchard, Carlos, \& Randolph, 1999).

Empowerment has been defined by Inglis (1997) as a procedure by which the role of individuals becomes refined to enable the organization to achieve desirable goals and adapt to changing environment. Human resources empowerment is giving attention to human capabilities of organizations and it is enabling individuals in a society or in a social system. In other words, empowerment means creating conditions in which people can do their work with inner motivation to achieve success. Rising expectations, globalization, and advanced technology are among the factors which caused organizations to act differently in comparison with traditional organizations. In traditional organizations the focus was on the human resources management, while in today's organizations in addition to energy, intellectual power and creativity are also under the control. Due to this, hierarchical methods of ordering and controlling would not be appropriate. Today's work environment requires managers and employees, who are capable of self-management and can provide solutions. Also, they should be creative and competent to recognize opportunities. In addition, they are expected to be knowledgeable and responsive to their own works which can be achieved by empowering. Given this concept, its outcome will be a positive work environment (Geminian, 2004).

For accreditation and assessing the ability of managers many empirical studies are undertaken in non-teaching organizations. But few studies have been conducted in educational organizations. If organizations cannot recruit efficient people, they will lose many opportunities and occasions. For the purpose of globalization or even for staying at this level, training and replacing new members are required in order to continue growing and progress. Although empowerment means different things to different people (Adams, 2008), there is a wide agreement about its use. To this end, the future belongs to those who have special plans and goals. In this context, higher education as a pioneer and effective system in all societies should be desirable in terms of human resources and it should consider all aspects quantitatively and qualitatively. So, the most important planning in the development of human resources and achieving the improvement of higher education system is 
empowerment of employees at universities. Clarke (2001) noted that although empowerment is a widely employed term, the way it is conceptualized varies. It is argued that empowerment can have a competitive advantage to an organization and despite the fact that many managers believe empowerment is desirable, but most organizations have faced problems in its implementation. Due to the fact that empowerment is a broad and controversial theme, this study moves in this direction in order to enhance the capabilities of managers and employees. The current study examines four components of organizational conditions, namely clear and challenging goals, evaluation of function, access to resources, and rewarding, and also it examines the effect of each of these factors on empowerment of managers.

\section{The Literature Review}

Empowerment has become a widely used management term and it refers to the act of granting power to individuals being empowered (Kanter, 1977; London, 1993). In the era of scientific management, particular attention was paid to methods and tools and mankind was marginalized. With the development of human relations movement some topics such as job satisfaction, job enrichment, democratic leadership, and empowerment of people were proposed. Nowadays, due to the presence of humans in organizations, human resources theories shape. Following this, we witnessed the importance of employees' morality, creation of energy, sense of responsibility, belief in goals, structural participation of people, and finally the presence of ethics in management issues.

These considerations imply that paying attention to the prosperity of employees in a stimulating relationship of belonging to an organization and identifying appropriate identity in accordance with it replace coercion and demands to be obeyed. McGregor's theory X and theory $\mathrm{Y}$ can be considered as a theoretical basis for the development of empowerment (Kopelman, Prottas, \& Davis, 2008). The outcomes of positive outlook at mankind in organizations let people participate in decision-making process, encouraging communication for improvement, attention to employees' comments and suggestions, giving opportunities to individuals for taking greater responsibilities, manager's commitment to its employees' selfactualization, and career development. In this case, particular attention is given to Maslow's hierarchy of needs including physiological needs, safety, belonging, respect, and selfactualization.

Positive outlook led successful leaders to focus their powers on empowering managers for achieving special purposes (Andrews, Herschel, \& Baird, 1996). Besides, this kind of outlook 
led to the preference for social management and democratic style in organization instead of using dictatorship and authority style (Hershey \& Kizzer, 1992). The concept of empowerment is mentioned in literature of human resources in different ways. Therefore, in 1950 academic recourses of management contained relatively large amount of this material, pointing out managers should have friendly behavior in relation with their employees which is known as human relations.

In 1960, it was stated that managers should be sensitive to the needs and motivations of employees (sensitivity training). In 1970, managers had to get help from employees (involving employees in the organization's affairs) and in 1980 they were required to form groups and follow the policy of collective decision-making (quality circles). The consistency of these subjects in 1990 and also the years later suggests that managers should learn how to develop empowerment. The concept of empowerment was first suggested in Lewin's social science (1951), in Herzberg's (1968) enrichment theory in increasing the control and individual's decision in a work, and in a research about self-alienation by Seeman (1959). Moreover, Kanter (1979) and Tannenbaum (1968) consider empowerment as participation in power and control which increases organizational effectiveness. In addition, Beckhard (1969) has examined it in a group. Also, the employees' involvement is investigated by Lawler (1992). All of these are involved in the formation of empowerment concepts and they are among the pioneers in the field of empowerment.

Kanter (1977), Block (1987), and Bennis (1989) refer to empowerment as a strategy that empowers subordinates as an effective organizational or managerial component. In any organization, empowerment depends on nature, culture, and needs of that organization. Other researchers examined it from different perspectives. For instance, self-control, career selfmanagement, group, and performance-based systems all are known as enabling or empowerment. Menon (1995) considers this as a kind of ability. Subjects, namely job enrichment, performance-based pay, etc., do not refer only to individual empowerment. However, these are management techniques which prepare the ground and provide measures to enable the employees to become accustomed to empowerment.

\section{Theoretical Framework}

Previous studies clearly indicate that various factors affected the human resources empowerment. Considering this, several models and structures of this factors and indicators have been studied. With regard to the foundations of the basic theory of research and studies 
by Abdollahi and Ashrafi Fashi (2013), and organizational conditions investigated by Spreitzer (1995), Scribner, Truell, Hager, and Srichai (2001), Abtahi and Abesi (2007), and Abdollahi and Naveh Ebrahim (2007), we used the variables which have the greatest impact in these studies, then we entered this variables into the model in order to assess them.

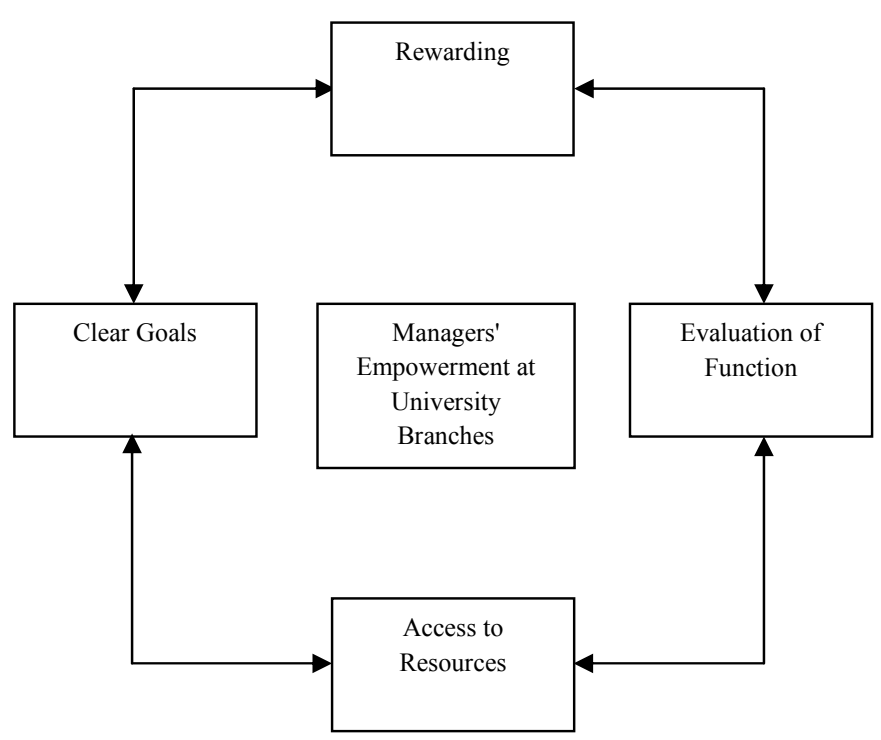

Figure 1. Conceptual model of research

\section{Research Hypothesis}

The main hypothesis of current study was as follows:

- Clear and challenging goals, evaluation of function, access to resources, and rewarding are determinants of empowering managers at universities in Ardabil.

\section{Methodology}

Considering the purpose of the present study, this research was a practical one, and it was carried out through a descriptive and survey method. Managers of Ardabil universities including chancellors, managers, and vice presidents of education, research, and studies participated in this study. In order to save time and to decrease travelling and transportation costs which constitute large amount of research costs, cluster sampling was applied. The units of analysis were the questionnaires that individuals responded.

The scope of the present study determines topics in the field of organizational behavior. The questionnaire included 5 questions about the demographic characteristics and 46 questions using a five-point Likert scale. Each question of the questionnaire was 
representative of variables which measured empowerment strategies of human resources at university branches. Respondents were presented with a questionnaire in their first calling. Then, in their second calling the questionnaires were collected and all were coded. Following this, the gathered data were entered into the SPSS and LISREL computer software. After their classification, descriptive statistics were calculated for the data, and finally in order to evaluate the fit of the model, reliability of the questionnaire, logical relationship between questions, and in order to determine the normality of the data, goodness-of-fit of a model (LISREL), Cronbach's alpha, Friedman (SPSS software), and Kolmogorov-Smirnov test (K-S test) were used, respectively.

In this study, the reliability of measuring instrument was 0.90 . In order to know whether the respondents' answers to the questions were the same or not, and for knowing ranking importance of each variable, Friedman's test was used. The results of this study are discussed from three aspects. First, we ensure that the respondents provided answers without prejudice. Second, it is important to know whether the respondents perceived the differences of the questions or not. Third, variables ranked according to their importance. The results indicated that the participants responded the questions without prejudice, they understood the differences between questions, and the respondents' opinions about the variables were not the same and they differed. Following this, the variables had different ranking.

\section{Results}

This study was undertaken with 220 respondents and Table 1 shows the descriptive statistics of demographic data.

$\mathrm{K}-\mathrm{S}$ test is a simple nonparametric test that quantifies a distance between the empirical distribution function of the sample and the cumulative distribution function of the reference distribution. In checking the normality of data, distributions are considered under the null hypothesis and they are tested at 5 per cent error level. If $p \geq 0.05$, then there would be no reason to reject the null hypothesis. In other words, the distribution of data would be normal.

Table 1

Descriptive Statistics of Demographic Data

\begin{tabular}{|c|c|c|c|}
\hline Sex & Frequency & Percentage & Cumulative Percentage \\
\hline Man & 197 & 89.5 & 89.5 \\
\hline Woman & 23 & 10.5 & 100 \\
\hline \multicolumn{4}{|l|}{ Age } \\
\hline $25-30$ & 7 & 3.2 & 3.2 \\
\hline $30-40$ & 98 & 44.5 & 47.4 \\
\hline $40-50$ & 97 & 44.1 & 81.8 \\
\hline
\end{tabular}




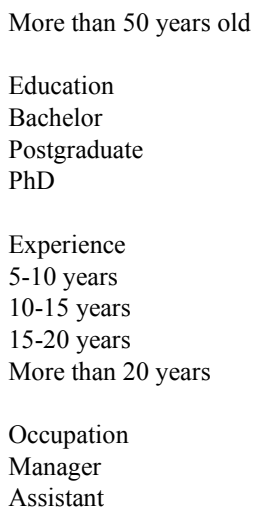

18

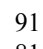

81

79

50
44

47

137
8.2

21.8

41.4

36.8

35.9

22.7

20
21.4

62.3

37.7
100

21.8

63.2

100

35.9

58.6

78.6

100

62.3

To test the normality of data the following hypotheses were set:

- $\mathrm{H}_{0}$ : Distribution of data for each variable is normal.

- $\mathrm{H}_{1}$ : Distribution of data for each variable is not normal.

Table 2 illustrates the results of $\mathrm{K}-\mathrm{S}$ test.

Table 2

Results of Kolmogorov-Smirnov Test

\begin{tabular}{|c|c|c|c|c|c|c|c|}
\hline & & Empowerment & $\begin{array}{c}\text { Evaluation of } \\
\text { Function }\end{array}$ & $\begin{array}{l}\text { Clear } \\
\text { Goals }\end{array}$ & $\begin{array}{l}\text { Access to } \\
\text { Resources }\end{array}$ & $\begin{array}{l}\text { Rewarding } \\
\text { System }\end{array}$ & Questionnaire \\
\hline \multicolumn{2}{|c|}{ Number } & 220 & 220 & 220 & 220 & 220 & 220 \\
\hline \multicolumn{2}{|c|}{$\mathrm{SD}$} & 0.26 & 0.35 & 0.35 & 0.37 & 0.35 & 0.26 \\
\hline Maximum & Absolute & 0.06 & 0.11 & 0.10 & 0.15 & 0.11 & 0.06 \\
\hline \multirow[t]{2}{*}{ Differences } & Positive & 0.06 & 0.11 & 0.10 & 0.15 & 0.11 & 0.06 \\
\hline & Negative & -0.06 & -0.10 & -0.06 & -0.07 & -0.06 & -0.04 \\
\hline \multicolumn{2}{|c|}{ Kolmogorov-Smirnov } & 0.97 & 0.99 & 1.02 & 1.24 & 1.00 & 1.88 \\
\hline \multicolumn{2}{|c|}{ P-Value } & 0.24 & 0.20 & 0.12 & 0.40 & 0.12 & 0.24 \\
\hline
\end{tabular}

From Table 1, it can be inferred that the level of significance was greater than error level (0.05) for all components. $P$-value demonstrated that null hypothesis was accepted. To be more precise, there was no reason to reject the hypothesis which indicated the sample was obtained from a normal distribution. In other words, the sample distribution was normal.

\section{Measurement Model of Independent Variables}

This model includes all the independent variables of research. The numbers written on the arrows represent the load factor of variables and indicators and also show their amount. Figure 3 illustrates the $t$-value of variables. Since these numbers were greater than 2 , it demonstrates that the represented model was reasonable and appropriate. 


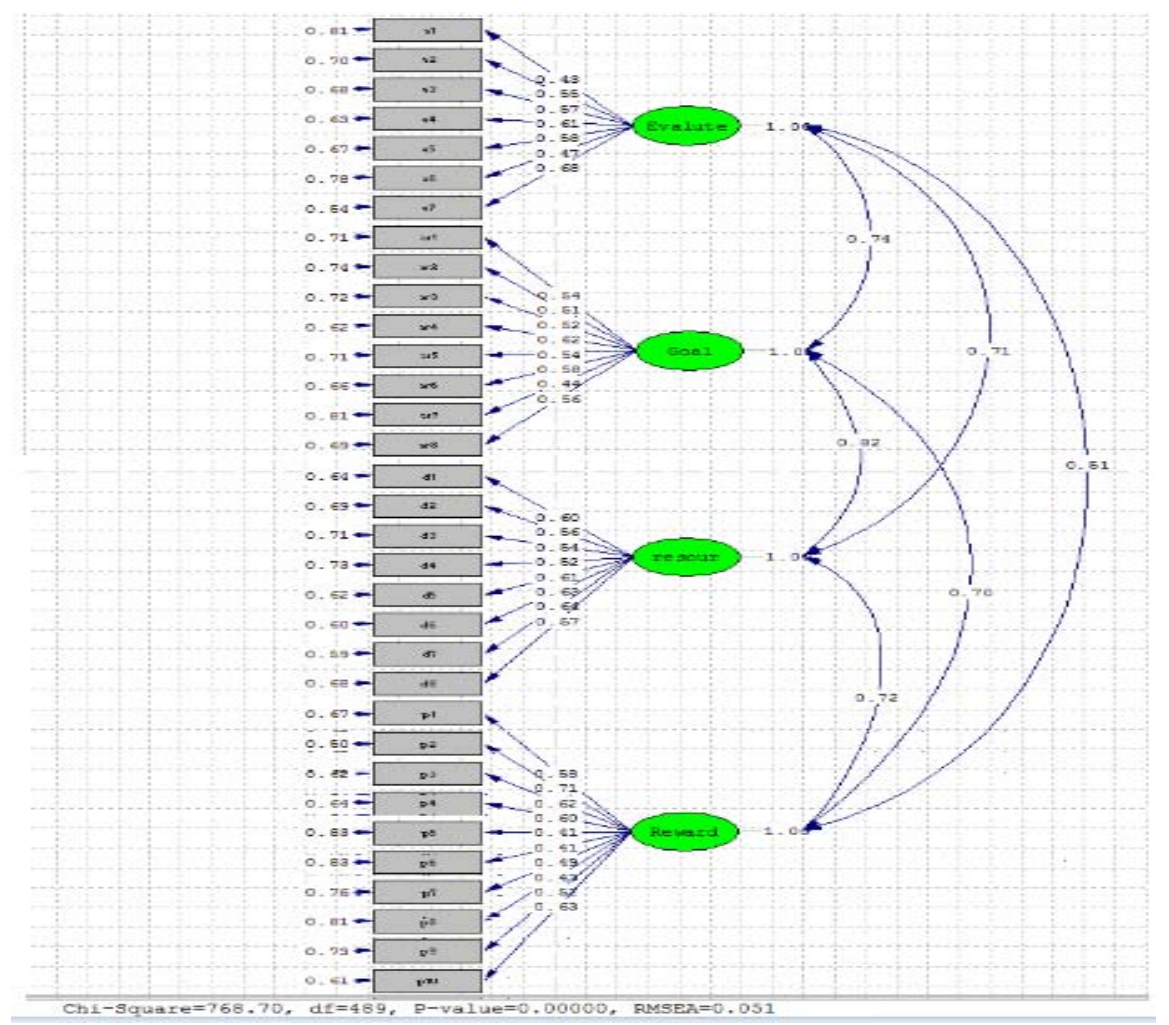

Figure 2. Standard coefficients of relationships between the independent variables

\section{Path Analysis}

To test the hypothesis, we used path analysis. The purpose of path analysis was to identify causality between variables of the conceptual framework. The structural model shown in Figure 4 represents the relationships between the research variables and managers' empowerment. 


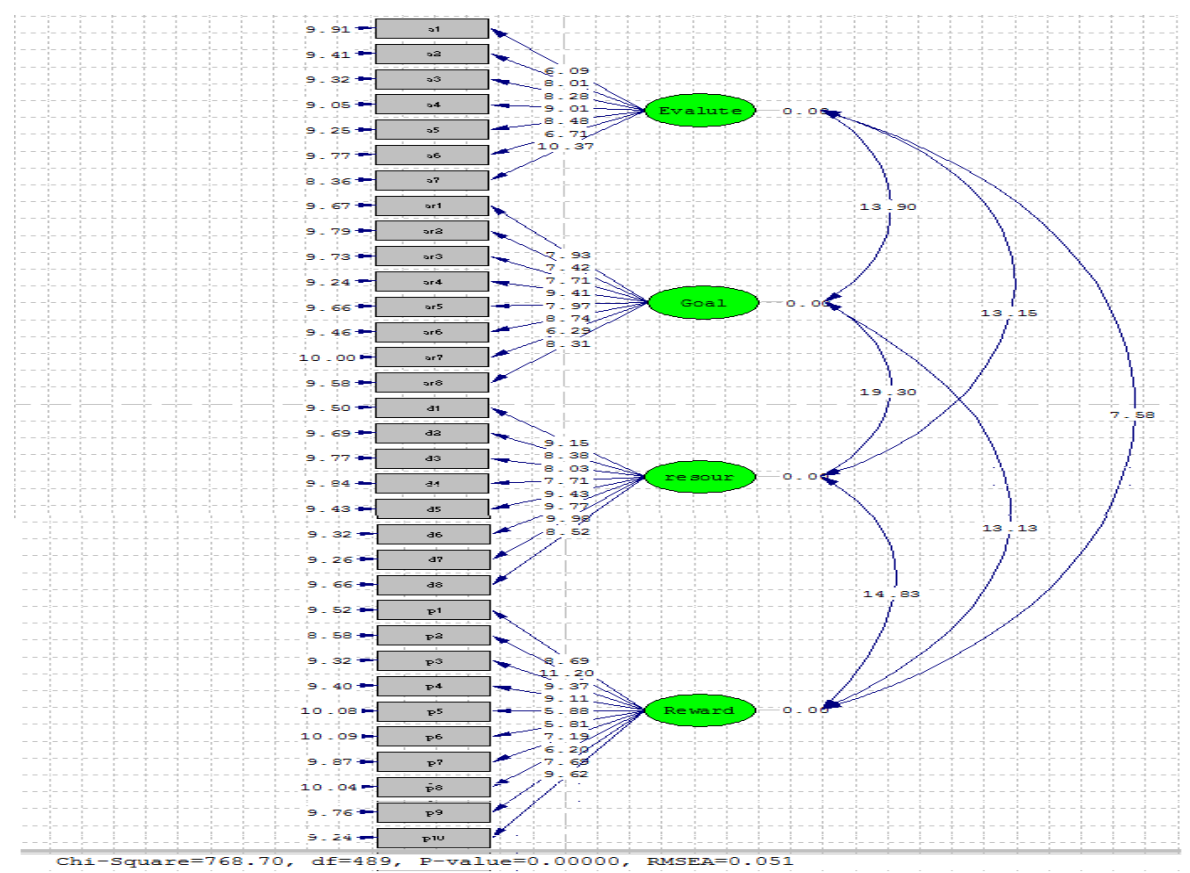

Figure 3. T-value coefficients of relationships between the dependant variables

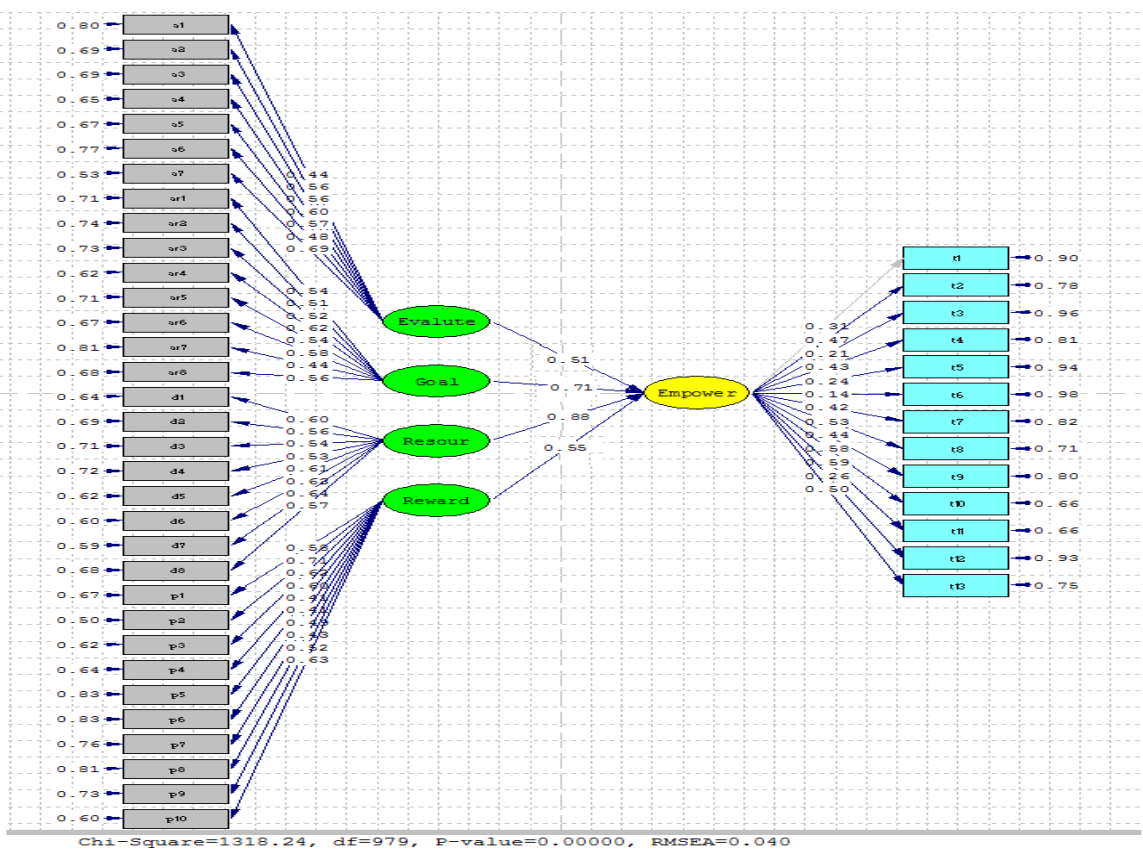

Figure 4. Standard coefficients of relationships between the research variables and managers' empowerment 


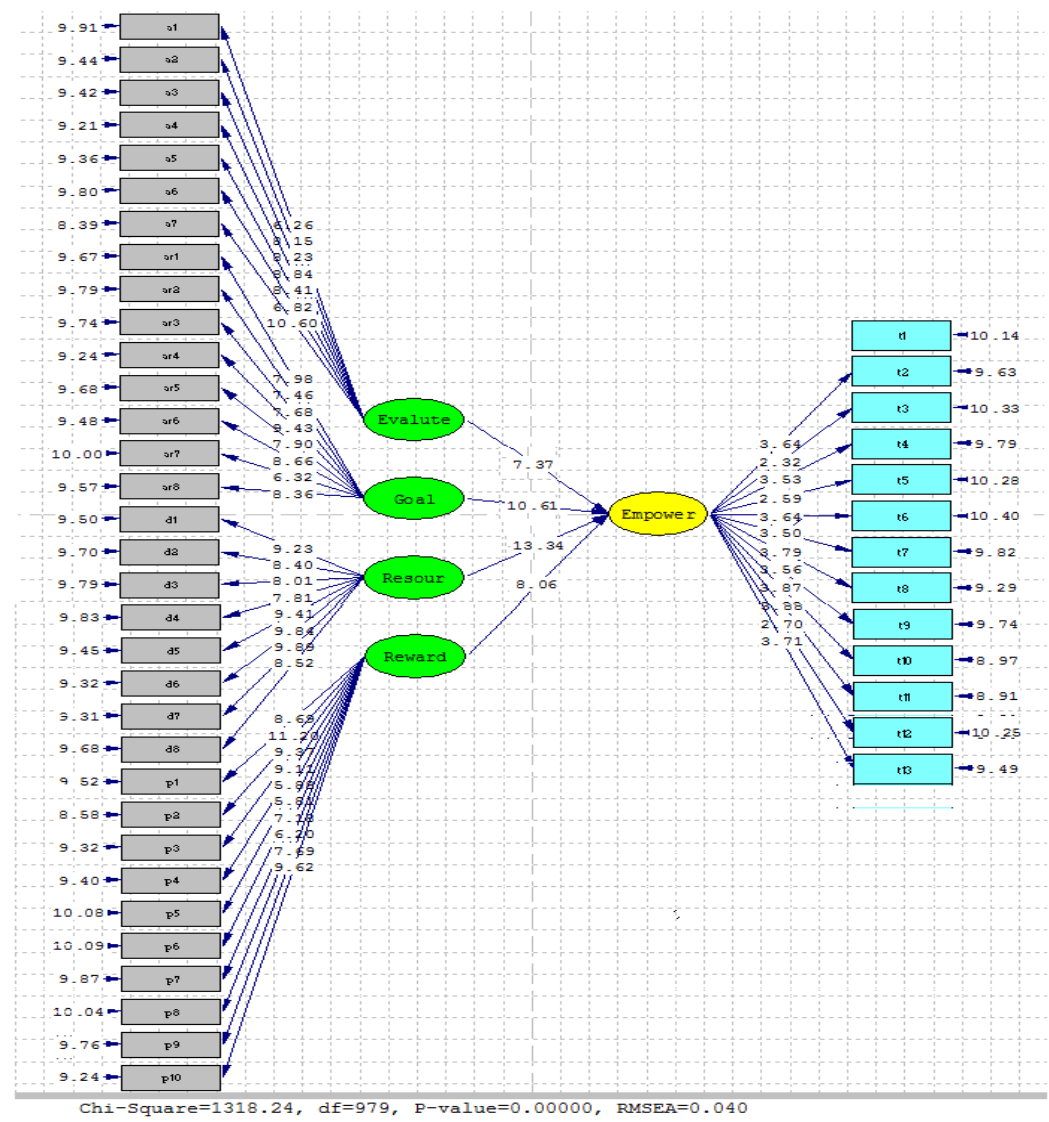

Figure 5. T-value coefficients of relationships between the research variables and managers' empowerment

Tables 3 and 4 show the load factor values of variables affecting the empowerment of managers. As Table 4 exhibit, load factor of access to variables was 88 per cent, clear goals 71 per cent, rewarding system 55 per cent, and evaluation of function was 51 per cent, all of which were acceptable. It can be inferred from Table 4 that access to resources was known as effective variable and evaluation of function recognized to have less effect. In other words, with an increase of one per cent in access to resources, empowerment increased about 88 per cent. Also, with an increase of one per cent in evaluation of function, empowerment increased about 51 per cent. Following this, with an increase of one per cent in clear goals and rewarding system, empowerment increased for about 71 per cent and 55 per cent, respectively. Based on these findings, it can be concluded that the variables including access to resources and clear and challenging goals explain managers' empowerment better. Indicators of the model fit are shown in Table 5. 
Table 3

First Level Factor Analysis of the Research Variables

\begin{tabular}{|c|c|c|c|c|}
\hline Variable & Items & Degree of Importance & T-Value & Load Factor \\
\hline \multirow{13}{*}{$\begin{array}{c}\text { Managers' } \\
\text { Empowerment }\end{array}$} & Question 11 & 1 & 3.88 & .59 \\
\hline & Question 10 & 2 & 3.87 & .58 \\
\hline & Question 8 & 3 & 3.79 & .53 \\
\hline & Question 13 & 4 & 3.71 & .50 \\
\hline & Question 5 & 5 & 3.64 & .47 \\
\hline & Question 9 & 6 & 3.56 & .44 \\
\hline & Question 4 & 7 & 3.53 & .43 \\
\hline & Question 7 & 8 & 3.50 & .42 \\
\hline & Question 1 & 9 & & .31 \\
\hline & Question 12 & 10 & 2.70 & .26 \\
\hline & Question 5 & 11 & 3.64 & .24 \\
\hline & Question 3 & 12 & 2.32 & .21 \\
\hline & Question 6 & 13 & 3.64 & .14 \\
\hline \multirow{7}{*}{ Evaluation of Function } & Question 7 & 1 & 10.60 & .69 \\
\hline & Question 4 & 2 & 8.84 & .60 \\
\hline & Question 5 & 3 & 8.41 & .57 \\
\hline & Question 2 & 4 & 8.23 & .56 \\
\hline & Question 3 & 5 & 8.15 & .56 \\
\hline & Question 6 & 6 & 6.82 & .48 \\
\hline & Question 1 & 7 & 6.26 & .44 \\
\hline \multirow{9}{*}{ Clear Goals } & Question 4 & 1 & 9.43 & .62 \\
\hline & Question 6 & 2 & 8.66 & .58 \\
\hline & Question 8 & 3 & 8.36 & .56 \\
\hline & Question 5 & 4 & 7.90 & .54 \\
\hline & Question 1 & 5 & 7.98 & .54 \\
\hline & Question 3 & 6 & 7.68 & .52 \\
\hline & Question 2 & 7 & 7.46 & .51 \\
\hline & Question 7 & 8 & 6.32 & .44 \\
\hline & Question 7 & 1 & 9.89 & .64 \\
\hline \multirow{7}{*}{ Access to Resources } & Question 6 & 2 & 9.84 & .63 \\
\hline & Question 5 & 3 & 9.41 & .61 \\
\hline & Question 1 & 4 & 9.32 & .60 \\
\hline & Question 8 & 5 & 8.52 & .57 \\
\hline & Question 2 & 6 & 8.40 & .56 \\
\hline & Question 3 & 7 & 8.01 & .54 \\
\hline & Question 4 & 8 & 7.81 & .53 \\
\hline \multirow{10}{*}{ Rewarding System } & Question 2 & 1 & 11.20 & .71 \\
\hline & Question 10 & 2 & 9.62 & .63 \\
\hline & Question 3 & 3 & 9.37 & .62 \\
\hline & Question 4 & 4 & 9.11 & .60 \\
\hline & Question 1 & 5 & 8.68 & .58 \\
\hline & Question 9 & 6 & 7.69 & .52 \\
\hline & Question 7 & 7 & 7.18 & .49 \\
\hline & Question 8 & 8 & 6.20 & .43 \\
\hline & Question 6 & 9 & 5.88 & .41 \\
\hline & Question 5 & 10 & 5.81 & .41 \\
\hline
\end{tabular}

Table 4

Second Level Factor Analysis of Relationships between the Variables and Managers' Empowerment

\begin{tabular}{|c|c|c|c|c|}
\hline Variable & Indicator & Degree of Importance & T-Value & Load Factor \\
\hline \multirow{4}{*}{$\begin{array}{c}\text { Managers' } \\
\text { Empowerment }\end{array}$} & Access to Resources & 1 & 13.34 & .88 \\
\hline & Clear Goals & 2 & 10.61 & .71 \\
\hline & Rewarding System & 3 & 8.06 & .55 \\
\hline & Evaluation of Function & 4 & 7.37 & .51 \\
\hline
\end{tabular}


Table 5

Results of the Model Fit

\begin{tabular}{|c|c|c|c|c|}
\hline Criteria of Model Fit & Indicator & Numbers & Permissible Amount & Result \\
\hline Chi-Square with Two Degrees of Freedom & $\mathrm{K}^{2} / \mathrm{df}$ & 1.34 & Less than 3 & Suitable Fit \\
\hline Root Mean Square Error of Approximation & RMSEA & 0.04 & Less than 1 & Suitable Fit \\
\hline Normed Fit Index & NFI & 0.85 & Above 0.9 & Acceptable \\
\hline Non-Normed Fit Index & NNFI & 0.95 & Above 0.9 & Suitable Fit \\
\hline Comparative Fit Index & CFI & 0.95 & Above 0.9 & Suitable Fit \\
\hline Incremental Fit Indices & IFI & 0.95 & Above 0.9 & Suitable Fit \\
\hline Goodness-of-Fit Index & GFI & 0.79 & Above 0.9 & Acceptable \\
\hline Adjusted Goodness-of-Fit Index & AGFI & 0.77 & Above 0.9 & Acceptable \\
\hline
\end{tabular}

According to Figure 4, the indicators of the model fit show the suitability of the measured variables. RMSEA was equal to 0.040 and since it was less than 0.08 , it indicated that the root mean square error of approximation was appropriate. To this end, the proportion of chisquare with two degrees of freedom was less than 3 . These considerations imply that the main indicators demonstrated a good fit of the model using the data. This highlights that the gathered data support the model.

\section{Ranking of Variables Using Friedman Test}

In this section, in order to rank the variables in terms of their effect on managers' empowerment, we used Friedman test. Friedman test is a nonparametric test, similar to variance analysis with repeated measures (within-group) which is used to compare mean scores between each rate $\mathrm{K}$ of group.

Table 6

Results of Friedman Test for Prioritization of the Research Variables

\begin{tabular}{lc}
\hline Dimensions & Explanation \\
\hline Number & 220 \\
Chi-Square & 9.31 \\
Degree of Freedom & 3 \\
Asymp. Sig. & 0.02 \\
\hline
\end{tabular}

The result of this test with 9.31 of chi-square and at 99 per cent of confidence level was significant at 1 per cent error level (Asymp. Sig. $=0.025$ ).

Table 7

Results of Research Variables Ranking

\begin{tabular}{ccc}
\hline Level & Mean Rank & Dimensions \\
\hline 1 & 2.62 & Evaluation of Function \\
2 & 2.62 & Access to resources \\
3 & 2.44 & Clear Goals \\
4 & 2.32 & Rewarding System \\
\hline
\end{tabular}


The results of mean rank showed that the evaluation of function and access to resources with 2.62 per cent of coefficient were at first levels of priority. Considering this, they had greatest impact on managers' empowerment. Clear goals with 2.44 per cent of coefficient and rewarding system with 2.32 per cent were at third and forth levels, respectively.

\section{Discussion}

The purpose of the present study was designing model of empowering managers by applying SEM at universities of Ardabil. The results of the analysis provided compelling evidence that the model of empowering managers was desirable at Ardabil universities. The findings of this study are in line with research done by Abdollahi and Naveh Ebrahim (2007), Horabadi Farahani (2006), Feizi and Zolfaghari Moghaddam (2009), Bakhtiari and Ahmadi Moghaddam (2011), Rahimi Dehghani and Baharlou (2014), and Abdollahi and Ashrafi Fashi (2013). Interestingly, these studies are in line with the findings of the present research and studies by Spreitzer (1995), Maeroff (1988), Cherniss (1997), Datnow and Castellano (2001), and Short and Rinehart (1992). In order to this, recommendations to improve the current situation are suggested in the following section.

It is believed that, in today's competitive world, the success of organization and managers depends on empowerment, and factors including total quality are possible in light of empowerment. Empowerment is a cultural movement and its rise depends on attitudes and views of community leaders and managers; because in a proper culture, organizational factors interact with empowerment and affect the success of empowerment process. The community leaders as a whole and managers and employees of universities and other organizations as part of a community by taking advantage of current research and by utilization of research results can take steps for empowerment of their members.

Review of the related literature showed that for empowerment of human resources, a general and systematic view should be used to provide a coherent planning and to use it for empowering human resources. Until the community leaders and organizations do not accept empowerment and do not provide favorable circumstances, people cannot become empowered. Due to this, the following items are suggested as applicable suggestions in order to stress the importance of empowerment and affective organizational factors to reduce volatility race and constant changes, to improve job skills of people and the working environment, and to increase the amount of work and job satisfaction. 


\section{Conclusion}

Considering the results, access to variables is main determinant of managers' empowerment. So, it is considered as one of the critical ways of empowerment, and it is a powerful system where people have legitimate authority for approved budget apportionment. People need to have human resources, administrative and technical, and financial resources support. Also, they need to have adequate space and essential equipment. They should get a reasonable allowance for resource allocation and they must have a schedule to provide these resources. In administration of these affairs, managers should have freedom to decide and they must be provided with the authority to make independent decisions. Direct supervision and ordering should be avoided, to the extent possible. A written report about their performance and feedback should be provided and their weaknesses and strengths should be discussed. In sum, the existence of evaluation system of managers' performance by the staff and students is a necessity for managers to become aware of the results of their activities and evaluations. It is worth noting that the time and resources are limited and allocation of limited resources for unlimited human needs is possible in the light of proficiency and knowledge management.

Organization's goals should be designed in a way that to be predictable, measurable, and realistic for both staff and managers. In addition, they should be consistent with intentions of the organization. Deadlines for achieving the goals should be specified. Clarity of organizational objectives must be taken into account. Consistent with this notion, objectives of universities and manager's duties must be determined; criteria and evaluation criteria of managers' work should be based on rules and managers need to receive the results of their own evaluations; managers are required to make every effort to create pleasant atmosphere for deliberation and critical debate and they need to be tolerant of opposing views; and they should encourage employees for developing plans and being creative. In addition, the existence of clear goals is also of primary importance because they increase motivation. In this regard, managers should be encouraged to have risk tolerance and to be risk-taking. It is recommended to take full advantage of managers' ideas in developing programs and to provide opportunities for new experiences and offering new suggestions.

Competency-based pay is suggested. This implies that rewarding should be based on the way people work and make progress in their work. It should depend on having risk-taking behaviors and becoming involved in creative works because displaying initiative is necessary in determining values at work. Reward plays a critical role in empowering the employees and managers. Also, the rewards, especially those associated with appreciation of top 
management, will motivate individuals so that they can use their potentiality for providing better performances. Providing opportunities for doing hard works, encouraging in the case of achieving success, considering top managers as a model and rewarding them are positively associated with managers' empowerment. Due to this, for appreciating and rewarding managers we can hold appreciation awards ceremony in order to create satisfaction; we can send notes for managers and their families toward appreciation of their work; and also we can provide welfare, resources, and facilities at work. The rewards can send the message that what is the purpose of organization. And, the individual's behaviors may be significantly influenced by rewarding.

Identification and careful evaluation of managers' function, appreciation, and rewarding based on their competency enhance the managers' sense of belonging to the organization and increase their responsibility. Following this, it is suggested that organizations can design an appropriate system of evaluation and develop performance indicators and give promotion to managers regarding their performance. For evaluation of function, it is recommended to give honest feedback to managers and to determine tips for showing feedback without aggression, criticism, or modifying elements of group. As a member of a group, choose a certain part including communicating or the way of solving problem, and ask peoples' opinion for achieving better performance.

\section{Suggestions for Further Research}

Regarding the nature of subject and due to the influence of factors, it is suggested that universities seriously consider these factors for empowering the managers, use them according to their influence, identify the obstacles, and proceed trying to solve the problems. The present study is not free from limitations. Considering the limitations and the study goal, to some degree, the current research was responsive to the need of research in the field of empowerment.

According to the results and the necessity of developing concepts in this area, the following suggestions are recommended for further research. This study focused exclusively on managers at universities. Applying the research design to other organizations and assessing employees in other educational centers are recommendations for further research. To increase the generalizability of the present study to other organizations, more data collection from various locations is needed. 
Since the purpose of the current study was designing model of empowering managers and investigating the impact of organizational factors on empowerment, it is suggested to assess the relation of other aspects of organization or to assess effects of on job trainings on employees' empowerment. Investigating and presenting a local model of empowerment in various organizations can be scope of other research. Exploring the effect of human resources empowerment on improving productivity of university employees can be of primary importance in future research. The development and expansion of information technology (IT) in organizations and its relationship with empowerment and investigating the effects of work psychology on empowerment of university employees or other organizations are recommendations for future research. To apply the results obtained and in order to have possible implications of results, localizations relevant to the outcomes of the studies by considering the temporal and spatial aspects of use are required.

\section{References}

Abdollahi, B., \& Ashrafi Fashi, S. (2013). Organizational conditions and administrative strategies in relation to empowering school administrators. Journal of New Thoughts on Education, 8(2), 91-114.

Abdollahi, B., \& Naveh Ebrahim, R. (2007). Empowerment of employees the golden key of human resource management $\left(1^{\text {st }}\right.$ ed.). Tehran: Virayesh Publication.

Abtahi, H., \& Abesi, S. (2007). Employee empowerment. Karaj: Management Research and Training Institute affiliated to the Ministry of Energy.

Adams, R. (2008). Empowerment, participation and social work ( $4^{\text {th }}$ ed.). London: Palgrave Macmillan.

Andrews, P. H., Herschel R. T., \& Baird, J. E. (1996). Organizational communication: Empowerment in a technological society. Boston: Houghton Mifflin Company.

Bakhtiari, H., \& Ahmadi Moghaddam, A. (2011). The roles of management strategies for empowering managers. Police Management Studies, 5(1), 39-53.

Bekhard, R. (1969). Organization development: Strategies and models. Reading, MA: Addison-Wesley.

Bennis, W. (1989). On becoming a leader. New York: Addison Wesley Publishing Company.

Blanchard, K. H., Carlos, J. P., \& Randolph, W. A. (1999). The 3 keys to empowerment. San Francisco: Berrett-Koehler.

Block, P. (1987). The empowered manager: Positive political skills at work. San Francisci: Jossey-Bass.

Cherniss, C. (1997). Teacher empowerment, consultation, and the creation of new programs in schools. Journal of Educational \& Psychological Consultation, 8(2), 135-152.

Clarke, N. (2001). Training as a vehicle to empower careers in the community: More than a question of information sharing. Health \& Social Care in the Community, 9(2), 79-88.

Datnow, A., \& Castellano, M. E. (2001). Managing and guiding school reform: Leadership in success for all schools. Educational Administration Quarterly, 37(2), 219-249.

Feizi, T., \& Zolfaghari Moghaddam, A. (2009). Identifying variables related to psychological empowerment in Qom education organization. Organizational Culture Management, 6(18), 123-151.

Geminian, V. (2004). An investigation into the relationship between freedom and commitment of high school teachers in Isfahan (Unpublished master's thesis). Isfahan University, Isfahan.

Hershey, G. L., \& Kizzer, D. L. (1992). Planning and implementing end-user information Systems. Cincinnati: SouthWestern Publishing Co.

Herzberg, F. (1968). One more time: How do you motivate employees? Harvard Business Review, 46(1), 53-62.

Horabadi Farahani, M. (2006). An investigation into the relationship between organizational structure and empowerment of employees (Unpublished master's thesis). Tehran University, Tehran.

Inglis, T. (1997). Empowerment and emancipation. Adult Education Quarterly, 48(1), 3-17.

Kanter, R. M. (1977). Men and women of the corporation. New York: Basic Books.

Kanter, R. M. (1979). Power failure in management circuits. Harvard Business Review, 57(4), 65-75.

Kopelman, R. E., Prottas, D. J., \& Davis, A. L. (2008). Douglas McGregor's theory x and y: Toward a construct-valid measure. Journal of Managerial Issues, 20(2), 255-271.

Lawler, E. J. (1992). Affective attachments to nested groups: A choice process theory. American Sociological Review, 57(3), $327-339$. 
Lewin, K. (1951). Field theory in social science. London: Tavistock Publication.

London, M. (1993). Relationships between career motivation, empowerment and support for career development. Journal of Occupational \& Organizational Psychology, 66(1), 55-69.

Maeroff, G. I. (1988). Teacher empowerment: A step toward professionalization. NASSP Bulletin, 72(511), 52-60.

Menon, S. T. (1995). Employee empowerment: Definition, measurement, and construct validation (Unpublished doctoral dissertation). McGill University, Canada.

Rahimi, E., Dehghani, A., \& Baharlou, R. (2014). Faculty members' view points on their empowering factors and developing a structural questionnaire. Iranian Journal of Medical Education, 13(1), 29-38.

Scribner, J. P., Truell, A. D., Hager, D. R., \& Srichai, S. (2001). An exploratory study of career and technical educational teacher empowerment: Implications for school leaders. Journal of Career \& Technical Education, 18(1), 46-57.

Seeman, M. (1959). On the meaning of alienation. American Sociological Review, 24(6), 783-791.

Short, P. M., \& Rinehart, J. S. (1992). School participant empowerment scale: Assessment of level of empowerment within the school environment. Educational \& Psychological Measurement, 52(4), 951-960.

Spreitzer, G. M. (1995). Psychological Empowerment in the Workplace: Dimensions, measurement and validation. Academy of Management Journal, 38(5), 1217-1496.

Tannenbaum, A. S. (1968). Control in organizations. New York: McGraw-Hill. 